\title{
Discover the Legal Concept in the Sociological Study
}

\section{${ }^{\Omega}$ Kadek Agus Sudiarawan', Putu Edgar Tanaya ${ }^{1}$, Bagus Hermanto ${ }^{1}$}

\author{
${ }^{1}$ Faculty of Law, Udayana University, Indonesia \\ ^email correspondence: agus sudiarawan@unud.ac.id
}

\begin{abstract}
This paper specifically examines the concept of law in a sociological study to find out how the law develops and how the law implemented or enforced as a unity in the legal system. This paper-based on the normative juridical method, using legal materials collected and analyzed using qualitative methods. The results show that the sociological of law studies as part of the activities of drafting legal products and the preparation of legal products is not just a juridical process. The processes of transformation from social desires into laws and regulations both in political and sociological contexts do not only occur during the formation of a regulation, continue and continually correct the legal products that produced. Law enforcement related to the sociology of law that observes the reality of how the law is working on different social structures, this scientific approach is expected to not only provide advice related to the development of legal science alone, but also must be applied, but unfortunately in the development of this science itself is not able to develop dynamically because observations that are not equally displayed in providing input to the development of legal protection in Indonesia.
\end{abstract}

Keywords: Legal Concept; Sociological; Legal Study.

Date of Submission: April 19, 2020

Date of Publication: May 20, 2020

DOI: http://dx.doi.org/10.33096/siiil.v3i1.69

\section{INTRODUCTION}

In general, the law is a whole collection of rules or rules governing the behavior in life together in its implementation with a sanction. ${ }^{1}$ However, until now there has not obtained an adequate legal understanding with reality. This is because the law has many aspects and forms, it covers all fields of human life, making it impossible for people to make an adequate and complex legal definition. ${ }^{2}$ The function of this law itself is to preserve the public interest, safeguard rights, and realize justice in a life together and to create an orderly and balanced community life. Law as an ideal concept has a close relationship with the abstract

${ }^{1}$ Suhardin, Yohanes. (2009). Fenomena Mengabaikan Keadilan dalam Penegakan Hukum, Mimbar Hukum, 21(2), 341-354, doi: https://doi.org/10.22146/jmh.16261, h. 344-345.

${ }^{2}$ Putri, Kania Dewi Andhika \& Arifin Ridwan. (2019). Tinjauan Teoritis Keadilan dan Kepastian dalam Hukum di Indonesia. Mimbar Yustitia, 2(2), 142-158, h. 144-145. 
conceptualization of justice. ${ }^{3}$ In this context, the law is to realize the ideas and concepts of justice accepted by the people of justice in concrete forms. The legal system itself is an order consisting of elements which include: legal structure, substance, and legal culture.

Legal notions as outlined above give us a clue that it is a human work as a reflection of the will and goals of the society it wants to achieve. Gustav Radbruch who stated that the purpose of the law covers three main things, inter alia justice (basic value), legal certainty (instrumental value) and utilization (practical value). ${ }^{4}$ Geny with ethical theory proposes a thesis that law aims solely to find justice, law functions to realize or realize justice. Jeremy Bentham argues that the purpose of the law is to guarantee the greatest happiness for humans in the greatest amount (the greatest happiness of the greatest number). ${ }^{5}$ Beyond that, some other thoughts about the purpose of the law, as stated in the mixed theory which states the main purpose of law order, so also Purnadi Purbacaraka and Soerjono Soekanto who argue that the purpose of the law is for interpersonal peace which includes interpersonal order and external peace personal intern. Meanwhile, Soebekti ${ }^{6}$ argued that the law served the state's goal of bringing prosperity and happiness to its people. It assumed that by serving the country's goals, the law will bring about justice and order.

Various objectives to be realized in society through the law made, as well as causing the duties and functions of the law diverse. The objectives of the law include the achievement of an orderly and peaceful society, realizing justice, and to bring prosperity and happiness or prosperity. Immanuel Kant conveys that the law is a coin with different sides. Rechmatigheid is said to be true if it is following applicable laws or regulations, while doelmatigheid focused on the value of truth in law is seen from the benefits for the public interest or the wider community. ${ }^{7}$ If the two sides are united then an ideal law will emerge that hangs the value of truth and usefulness, but if one condition must be chosen one, then the benefit must be chosen or prioritized. Jeremy Bentham stated that law can be categorized as a good law if it can provide happiness to the majority of the community. ${ }^{8}$ This reflects that benefit as a legal objective is an important part of law enforcement in Indonesia and law enforcement shall be based on three main elements namely certainty, justice, and expediency, and must be carried out both in normal, peaceful conditions and due to violations of the law.

\footnotetext{
${ }^{3}$ Kartika, I Gusti Ayu Putri \& Wijayanti, Asri. (2010). Belajar Argumentasi Hukum, Cetakan Pertama, Humanika Cerdas Harmoni, Surabaya, h. 29-30.

${ }^{4}$ Sutiyoso, Bambang. (2010). Mencari Format Ideal Keadilan Putusan dalam Peradilan. Jurnal Hukum Ius Quia lustum, 17(2), 217-232, doi: https://doi.org/10.20885/iustum.vol17.iss2.art3, h. 224-225.

${ }^{5}$ Wijayanti, Widya. (2013). Eksistensi Undang-undang sebagai Produk Hukum dalam Pemenuhan Keadilan bagi Rakyat (Analisis Putusan Mahkamah Konstitusi Nomor 50/PUU-X/2012). Jurnal Konstitusi, 10(1), 179-204, doi: https://doi.org/10.31078/jk\%25x, h. 186-187.

${ }^{6}$ Maggalatung, A Salman. (2014). Hubungan antara Fakta Norma, Moral, dan Doktrin Hukum dalam Pertimbangan Putusan Hakim, Jurnal Cita Hukum, 2(2), 185-192, doi: 10.15408/jch.v1i2.1462, h. 186-187.

${ }^{7}$ Pujirahayu, Esmi Warassih (2011). Pranata Hukum: Sebuah Telaah Sosiologis, Badan Penerbit Universitas Diponegoro, Semarang, h. 24-25.

${ }^{8}$ Dwisvimiar, Inge. (2011). Keadilan dalam Perspektif Filsafat IImu Hukum. Jurnal Dinamika Hukum, 11(3), 522531, doi: http://dx.doi.org/10.20884/1.jdh.2011.11.3.179, h. 523.
} 
The law as a social rule cannot be separated from the values that apply in a society, it can even be said that the law is a reflection and concretization of the values that existed once in force in society. The law always follows the values that become a common awareness among certain people and be effective in regulating their lives and closely with the sociology of law. ${ }^{9}$ The scope of the study of the sociology of law is a legal study in the perspective of social science is an effort to do legal construction based on existing social phenomena. ${ }^{10}$ The behavior of the people studied is behavior that arises from interacting with the existing norm system. This interaction arises as a form of community reaction to the implementation of a positive statutory provision and can also be seen by people's behavior as a form of action towards the formation of a positive legal provision. Faced with the nature of legal science with all its limitations, social law theory is needed to broaden scientific insights from the law to get out of the confines of old paradigms normative and evaluative only. Thus, the study of legal sociology is a study whose object is a legal phenomenon, but uses the optics of social science and sociological theories, so that it is often misinterpreted not only by non-law circles but also from the legal community itself.

Associated with National Law, national law is defined as a law or regulation based on the ideology and state constitution, namely Pancasila and Indonesia Constitution. National law is nothing but a legal system that originates from the nation's cultural values that have existed for a long time and are developing now. ${ }^{11}$ The national legal system is a legal system (covering material and formal, basic and sectoral) that is built based on Pancasila and Indonesia Constitution, and applies throughout Indonesia. The government then established a policy to utilize the three existing legal systems in Indonesia, namely the customary legal system, the Islamic legal system, and the west (the Netherlands) as its raw material. ${ }^{12}$ Ironically, that situation not succeeded in having our national legal system. It seems that what is meant by the national legal system is still limited to ideals and who knows when it can be realized regularly. ${ }^{13}$

Indonesia itself in its development is still experiencing a variety of problems in building a strong national legal system, it is proven that there are still so many corrections that must be made starting from the development process or the formation of law to the process of law enforcement in this country which is still so problematic, so it becomes important and interesting than when trying to analyze the ideal "law" concept from a sociological perspective, in this case, it must be analyzed more deeply about how the law was built, how the law developed and how

\footnotetext{
${ }^{9}$ Soekanto, Soerjono. (1981). Perspektif Sosiologi Hukum terhadap Pembinaan Hukum. Jurnal Hukum dan Pembangunan, 11(5), 461-466, doi: http://dx.doi.org/10.21143/jhp.vol11.no5.864, h. 462.

${ }^{10}$ Kusumah, Mulyana W. (1981). Perkembangan dan Ruang Lingkup Sosiologi Hukum. Jurnal Hukum dan Pembangunan, 11(1), 63-72, doi: http://dx.doi.org/10.21143/jhp.vol11.no1.838, h. 68.

${ }^{11}$ Sidharta, Bernard Arief. (2009). Refleksi tentang Struktur IImu Hukum Sebuah Penelitian tentang Fundasi Kefilsafatan dan Sifat Keilmuan IImu Hukum sebagai Landasan Pengembangan IImu Hukum Nasional Indonesia, Cetakan Ketiga, Mandar Maju, Bandung, h. 184-185.

${ }^{12}$ Subiharta, Subiharta. (2015). Moralitas Hukum dalam Hukum Praksis sebagai Suatu Keutamaan. Jurnal Hukum dan Peradilan, 4(3), 385-398, doi: http://dx.doi.org/10.25216/JHP.4.3.2015.385-398, h. 393.

${ }^{13}$ Mustaghfirin, H. (2011). Sistem Hukum Barat, Sistem Hukum Adat, dan Sistem Hukum Islam menuju sebagai Sistem Hukum Nasional sebuah Ide yang Harmoni, Jurnal Dinamika Hukum, 11(1), 89-96, doi: http://dx.doi.org/10.20884/1.jdh.2011.11.Edsus.265, h. 90-93.
} 
the law was implemented or enforced in a sociological perspective to then produce a product of law and strong law enforcement as needed and aspired by the people of Indonesia.

This issue encourages this article to be compiled with a heading related to Discover Legal Concepts in Sociological Studies to be analyzed in-depth concerning how the law was developed, how it develops and how the law is implemented or enforced as a unity in the legal system, specifically related to the analysis of the concept of " law" in the sociological studies.

\section{METHOD}

This paper was conducted by using normative juridical methods by focusing on norms problems with prescriptive disciplines. ${ }^{14}$ This paper-based on preliminary research with collecting and analyzing primary legal materials and secondary legal materials using library research ${ }^{15}$ to answer the legal problem in this study concerning how the law was developed, how it develops and how the law is implemented or enforced as a unity in the legal system, specifically related to the analysis of the concept of " law" in the sociological studies.

\section{ANALYSIS AND DISCUSSION}

\section{A. Legal Formation and Development}

In the formation or development of law in the form of drafting legislation must be able to represent the role of law as a tool to dynamize the community. Thus the function of the legal ideal in a state that is changing can accommodate all the complex dynamics of society such as Indonesia. ${ }^{16}$ Through normalizing behavior, the law enters all aspects of life, especially providing a framework for the relationships made by members of one community to another. Law is a necessity inherent in social life itself.

Legal ideals that contain benchmark values have a very important role and function in the process of drafting democratic laws and regulations. ${ }^{17}$ The law is designed in such a way as to be an orderly and orderly legal structure. The legislation made should not cause conflict with one another. The ideal of law should color the entire legal structure or in other words, the meaning contained in the ideals of law must be realized in a democratic legal order. ${ }^{18}$ Formation of legislation is not merely a juridical activity, but rather an interdisciplinary activity. The method of forming laws and regulations determines whether a statutory regulation can achieve its

${ }^{14}$ Sonata, Depri Liber. (2014). Metode Penelitian Hukum Normatif dan Empiris: Karakteristik Khas dari Metode Meneliti Hukum. Fiat Justisia: Jurnal IImu Hukum, 8(1), 15-35, doi: 10.25041/fiatjustisia.v8no1.283, h. 25-27.

${ }^{15}$ Choudhury, Nafay. (2017). Revisiting Critical Legal Pluralism: Normative Contestations in the Afghan Courtroom. Asian Journal of Law and Society, 4(1), 229-255, doi: 10.1017/als.2017.2, p. 231.

${ }^{16}$ Sirajuddin, M. (2015). Eksistensi Norma Agama dan Pancasila dalam Pembentukan Peraturan Perundangundangan, Nuansa: Jurnal Studi Islam dan Kemasyarakatan, 8(1), 27-39, doi: http://dx.doi.org/10.29300/nuansa.v8i1.323, h. 30-31.

${ }^{17} \mathrm{Jati}$, Rahendro. (2012). Partisipasi Masyarakat dalam Proses Pembentukan Undang-undang yang Responsif. Jurnal Rechtsvinding, 1(3), 329-342, h. 331-332.

${ }^{18}$ Amarini, Indriati. (2017). Evaluasi Aktualisasi Pancasila melalui Harmonisasi Hukum, Kosmik Hukum, 17(2), 8092, doi: 10.30595/kosmikhukum.v17.i2.2326, h. 85. 
objectives in the best possible way. ${ }^{19}$ For this reason, assistance from legal sociology, other social sciences, and planning knowledge is very much needed. In the formation of a legal product in the form of laws and regulations sociological later became an important element besides the academic, juridical, political, and physiological aspects to be able to produce a legal product that is representative of what is needed by the community in its development.

The existence of a legal institution is an indicator or the key implementation of a policy. In the explanation of Article 1 Paragraph (3) Indonesian Constitution expressly states that the state of Indonesia is a state of law. Eine Rechtstaat, a State based on Law, a State governed by Law. That means, the law is not a product formed only by high state institutions, but also which underlies and directs the actions of these institutions. Law is the basis and guide for all aspects of social, national, and state activities. To make the process of drafting legislation better, the legislators should be aware and truly understand two main things, namely: concept and language. Clarity of concepts is needed to assist and guide the design of a legal product, both in developing substantive policies and in communicating them. Awareness is needed for legal scientists to participate in thinking about the problem of designing and planning legal products based on solid conceptual thoughts. ${ }^{20}$

If a legal institution is understood as a system, then all the rules that are in it must not conflict with each other. In the formation and enforcement of the law as a system, it always receives input from other fields which in turn produce outputs that are channeled into society. If understood as a norm system, each of the highest and lowest laws and regulations must be a fabric of a system that does not conflict with each other. L.M Friedman states that the heart of the system is the way in turning an input into an output. The structure of the legal like the system is like some gigantic computer program, ended to deal with millions of problems that are fed turned into the machine. ${ }^{21}$

The ideal of law can be understood as the construction of the mind which is a must for directing the law to the ideals desired by society. Rudolf Stammler argues that the ideals of law function as regulative and constitutive benchmarks. ${ }^{22}$ Without the legal ideal, the legal product produced will lose its meaning. The ideal of law must be understood as a basis and binding in the formation of statutory regulation. In making laws and regulations, and in the process of embodying values contained in the law into legal norms, it is very dependent on the level of awareness and appreciation of the legislators (the people's representatives).

\footnotetext{
${ }^{19}$ Hartanto, Wenda. (2015). Kesadaran Hukum sebagai Aspek Dasar Politik Hukum Legislasi: Suatu Tinjauan Filsafat. Jurnal Rechtsvinding, 4(3), 469-483, h. 480-481.

${ }^{20}$ Yusa, I Gede \& Hermanto, Bagus. (2017). Gagasan Rancangan Undang-undang Lembaga Kepresidenan: Cerminan Penegasan dan Penguatan Sistem Presidensiil Indonesia. Jurnal Legislasi Indonesia, 14(3), 313-324, h. 315316.

${ }^{21}$ Mulyani, Lilis. (2010). Pendekatan Sosial dalam Penelitian Hukum, Jurnal Masyarakat dan Budaya, 12(3), 3556, doi: http://dx.doi.org/10.14203/jmb.v12i3.150, h. 48-49.

${ }^{22}$ Herlina, Ning. (2018). Cita Hukum Pancasila dapat Berkembang dalam Batang Tubuh Undang-undang Dasar Republik Indonesia 1945, Lex Librum: Jurnal IImu Hukum, 4(2), 673-679, doi: http://doi.org/10.5281/zenodo.1286112, h. 674-675.
} 
Krems even argues that the formation of the contents of statutory regulation is a joint field of legal politics (Rechtspolitik) with the sociology of law (Rechtssoziologie). ${ }^{23}$ By including the sociological stage as part of the activities of forming or drafting legal products, it can teach us that the preparation of legal products is not just a juridical process. First, in the macro process, the preparation of a legal product (regulation) in the sociological stage takes place in society is determined by the availability of materials in it. In the sociological context, the community factor is the place where an event, problem, or social objective arises. Second, the so-called political stage is the stage to try to identify the problem and then formulate it further. All ideas and ideas that were successfully identified in the sociological process were further sharpened in more critical discourse by the forces that exist in society. ${ }^{24}$

The processes of transformation from social desires into laws and regulations both in political and sociological contexts do not only occur at the time of the formation of a regulation. Even at the operational stage, these processes continue and continually correct the legal products that have been produced. After the sociological and political stages are passed, then the lawmaking process enters the last stage which is called the juridical stage, at this stage, it focuses more on the problem of drafting and organizing problems that are arranged into legal formulations. The state of law cannot be understood regardless of the social context. Looking for a model for the preparation of democratic laws and regulations, it is expected to produce responsive legal conditions so that it can respond to various demands of the community. This can be achieved if legal and political aspirations are integrated, access is enlarged by the integration of legal and social advocacy.

The way to make a good legal product or a good method must be populist, meaning to side with the interests of the people. In making a legal product or a State Administrative Decree, several methods need to be considered by the decision-maker, namely:

\section{Materiele theorie}

Leopold Pospisil has 3 (three) frameworks for thinking, namely:25

a. Legal products in a country can be developed into 2 (two) large groups, namely law made by the authorities (made in authority) or written law (authoritarian law) and laws that live in a society or unwritten laws, customs, and conventions (common law).

b. The two legal groups above have advantages and disadvantages, but the advantages and disadvantages are inversely proportional, as compared, first, the strengths of the law made by the authorities or written law are having legal certainty and high forced power, meaning that every birth must be binding. While the shortcomings are static and the objectivity of justice is

\footnotetext{
${ }^{23}$ Hartanto, Wenda., Op.Cit., h. 482.

${ }^{24}$ Simatupang, Taufik H. (2019). Mendudukkan Konsep Executive Review dalam Sistem Hukum Ketatanegaraan Inonesia, Jurnal Penelitian Hukum De Jure, 19(2), 217-230, doi: http://dx.doi.org/10.30641/dejure.2019.v19.217-229, h. 224-225.

${ }^{25}$ Sahlan, Sartono. (2010). The Other Laws di Era Otonomi Daerah (Studi Antropologi Hukum), Pandecta: Jurnal Penelitian IImu Hukum, 5(2), 149-159, doi: https://doi.org/10.15294/pandecta.v5i2.2301, h. 152-153.
} 
difficult to realize even though one of the aims of law is justice because the law is used through the eyes of the authorities. Second, the advantages of living law in the community or unwritten law (common law) are dynamic in nature and the objectivity of justice is easily realized because of the law originating from the community and through the community's glasses. While the drawback is having legal certainty and low coercive power, whenever people get bored they will leave the regulation.

c. From this theory, it can be concluded that a good legal product is a legal product with as much material as possible taken from the common law (the public) but the container is given an authoritarian law form.

\section{Formelle theorie}

Rick Dickerson explains that a good legal product shall fulfill three requirements, ${ }^{26}$ inter alia first, completely manage the problem. This means that in making a legal product, the problem must be completely resolved and comprehensive so that it can last for a long period such as the Criminal Code, the Civil Code. Second, a little might contain the provisions of the delegation of the law. It means that it is tried as little as possible not to give the delegation its authority. Third, the provisions shall not to drafted as elastic in nature. The point is that in making legal products, avoid the rubber article, the unclear article.

\section{Philosophy of theory}

Jeremy Bentham as elaborated with Choky Ramadan explains that a good legal product must have 3 (three) cumulative applicable characteristics, ${ }^{27}$ namely, first, philosophical applicable, legal products must reflect the philosophy of life of a nation such as the Indonesian nation, Pancasila. Second, it applies sociologically, reflecting the legal awareness of the community and adjusting to the state of the community where the law applies. Third, juridical applicable, the law is likened to a spear that has two sharp ends, which are just and right. Fair is a balance between rights and obligations. Right is a match between rules and deeds. Fair is not necessarily true, true is not necessarily fair, if fair and true meet, it is called peaceful. So that it is true and fair it must be combined to match.

If a legal product is made by referring to the wrong 3 (three) methods of making the legal product, then the decision or legal product created can meet all the needs of the community, so that the goal of creating a just and prosperous society can be realized because the legal product runs well and smoothly.

\section{B. Legal Developments}

Development that emphasizes the economic field and growth paradigm can be successful if supported by political stability. Therefore, according to Alfian, the new political

\footnotetext{
${ }^{26}$ Fadli, Muhammad. (2018). Pembentukan Undang-undang yang Mengikuti Perkembangan Masyarakat. Jurnal Legislasi Indonesia, 15(1), 51-61, h. 55.

${ }^{27}$ Ramadhan, Choky. (2018). Konvergensi Civil Law dan Common Law di Indonesia dalam Penemuan dan Pembentukan Hukum, Mimbar Hukum, 30(2), 213-229, doi: https://doi.org/10.22146/jmh.31169, h. $216-217$.
} 
format used to ensure stability is to build a strong executive institution. In the course of history, these conditions caused a shift in several fundamental things in development. ${ }^{28}$ First, the development strategy and implementation with a growth model, it turns out to have implications that are too far away, not working trickle-down effects, widening the gap between social strata and between regions, the destruction of the small business sectors including the domestic and informal industrial sectors. Second, growing and the development of impressive regimes that tend to corrupt or develop corruption, collusion, manipulation and nepotism, the elimination of people's political participation, limited press freedom, the very minimal role of society in decision making, even violations of human rights and deprivation of rights the rights of the people who surfaced. This model of state policy formation is elitist because only they know the needs of the people and try to fulfill them, without having to involve the people because they are considered passive, apathetic and information poor.

The dynamics of development with the characteristics of the New Order cause legal products to be seen as political products, the law is only a tool to realize political goals. The legal order that was developed became very elitist and conservative because the formation process was very centralistic and not participatory. Thus, what constitutes law is what is desired by political power and rulers for the desired interests. The type of law is ultimately repressive, which requires a level of compliance of citizens that is near absolute (Submissive Compliance).

The transfer of power to Habibie in May 1998 changed the direction of Indonesia's leadership. The development reform cabinet tries to respond to the demands and aspirations of the people. But in reality, the people's aspirations towards total change are difficult to realize. This kind of situation is caused by a large number of New Order elements entering these periods. In June 1999 the General Assembly of the People's Council appointed Abdurrahman Wahid (well known as Gus Dur) and Megawati as President and Vice President. The government at that time was expected to be able to respond and realize the demands of reform by solving cases that smelled of corruption. The paradigm shift was followed by the formation of legislation accompanied by consistent law enforcement. Law is responsive, as a facilitator who can respond to social aspirations and needs. ${ }^{29}$

The period after that, Megawati and Hamzah Has were entrusted to lead the country with a pile of complex national problems that were difficult to deal with. The legal and enforcement steps seem not to show significant participation in the interests of the community at large. It must be realized that a life of society, nation and state is in dire need of an order that can guide us in the administration of a rule of law as mandated in the 1945 Constitution.

${ }^{28}$ Setyowati, Peni Jati. (2016). Fungsi Filsafat, Agama, Ideologi dan Hukum dalam Perkembangan Politik di Indonesia, Yuridika, 82-107, doi: 10.20473/ydk.v31i1.1957, h. 95, 99.

${ }^{29}$ Yani, Ahmad. (2018). Sistem Pemerintahan Indonesia: Pendekatan Teori dan Praktek Konstitusi Undangundang Dasar 1945, Jurnal Ilmiah Kebijakan Hukum, 119-135, doi: http://dx.doi.org/10.30641/kebijakan.2018.v12.119135 , h. $129-130$. 
Experience in Indonesia proves that legal products are strongly colored by their political configurations. ${ }^{30}$

The hegemony of political power that has entered the economic field has contributed to and is very important in the product of law. The law experienced a decline because the order at that time was based on the deterioration of the paradigm of power, centralism, and monolithic power. Law based on the power paradigm presents undemocratic law, which is a totalitarian legal system. Such a legal order also shows the existence of a hierarchy, but the hierarchy is not based on legal logic but the logic of power. Such a law rejects an impersonal approach and is only a means to justify or justify the actions of the authorities and as a means of guarding stability. This reality shows that the law is not an institution that can be released from its social context. That is, normative provisions still require lengthy handling to realize their goals in society.

According to Jeremy Bentham that the law aims to provide the greatest happiness to as many people as possible ${ }^{31}$ and for Indonesia itself, the purpose of the law is to form an Indonesian government that protects all Indonesian people and all Indonesian bloodshed and to promote public welfare, educate the nation's life and participate in carrying out world order based on independence, eternal peace, and social justice. Based on the above understanding framework, according to the enlightenment philosophers, the established legal order fulfills the criteria. First, the law must not only be a tool to achieve rationality, but the law itself must be rational. Secondly, to ensure that rational law work can realize its objectives, efficient action must be supported by the law enforcement device. Third, the importance of putting a substance into a legal form is very closely related to the influence of the social structure of society, because the law should realize its goals.

Perhaps there is no better and more appropriate way to describe Indonesian society today that is changing rapidly and is pretty basic. Indonesia is a society undergoing transformation, which can be interpreted as the rearrangement of elements from a society, which has been and certainly disrupts the existing value system.

The most fundamental problem is dominating the paradigm of power, which has resulted in the law not being able to play its true role as a tool for realizing prosperity. The Indonesian people who adopted Max Weber's modernization theory a lot, need to know their views on the transformation process. Max Weber concluded that the transformation of European society into a capitalist society because in the body of European society itself contained

${ }^{30}$ Aryani, Nyoman Mas \& Hermanto, Bagus. (2018). Gagasan Pengaturan yang Ideal Penyelesaian Yudisial maupun Ekstrayudisial Pelanggaran Hak Asasi Manusia di Indonesia. Jurnal Legislasi Indonesia, 15(4), 369-383, h. 371-372.

${ }^{31}$ Buana, Mirza Satria \& Vikalista, Ellisa. (2019). Kontestasi Negara, Agama Mayoritas dan Hak Asasi Manusia (HAM) dalam Peraturan Daerah Bernuansa Syariah, Arena Hukum, 12(1), 43-63, doi: https://doi.org/10.21776/ub.arenahukum.2019.01201.3, h. 49. 
"potential", cultural ingredients that encourage the birth of the capitalist spirit. ${ }^{32}$ Transformation occurs when the cultural fibers that interfere with the firm's plait of a culture of society have decayed and can no longer function as a cultural binder. While related to globalization, globalization has been a central issue in the last few decades and has been a discussion at various levels of thought. 33

Over the last few decades, Indonesia has increasingly entered and become part of the globalization process, particularly in the process of restructuring the global economy. This means that Indonesia must immediately conduct legal arrangements. In structuring such law, Indonesia not only pays attention to the legal ideals and politics of national law and local characteristics but should also pay attention to trends that have been recognized by countries that have followed global trends, which appear in international instruments, such as declarations, conventions, codes of conduct and others. And to prevent people from customer culture a democratic climate needs to be created to foster legal awareness and critical awareness for all levels of society in realizing institutions or institutions that can provide protection and justice. So that civil society can be achieved as a form of society in which there is no discrimination, the freedom to act in all matters relating to social problems.

\section{Implementation and Law Enforcement}

In essence, the law contains ideas or abstract concepts. Even though it is abstract, it is made to be implemented in everyday social life. Law enforcement will touch on many other aspects that surround it. One thing is certain, that the effort to realize an idea or value always involves the environment as well as various other factors.

A striking characteristic in talking about the sociology of law enforcement is that law enforcement is not a definite action, namely applying the law to an event, which can be likened to drawing a straight line between two points. ${ }^{34}$ In legal science, such a method is called an automatic machine model and the work of enforcing the law becomes an automatic activity. Here the law is seen as a clear and definite variable, as well as events that provoke the application of the law so that everything seems simple. In reality, the situation is not like that, but what happens is that law enforcement contains choices and possibilities, because it is confronted with a complex reality. In normative jurisprudence, this complexity is ignored, whereas the sociology of law as an empirical science does not neglect it at all. ${ }^{35}$

Marc Galanter has a good term to describe the workings of the sociology of law, which is looking at the law "from the other end of the telescope." It is said that the dominant legal

${ }^{32}$ Kusumah, Mulyana W., Op.Cit., h. 69. h. $50-51$.

${ }^{33}$ Agustiwi, Asri. (2016). Hukum sebagai Instrumen Politik dalam Era Globalisasi, Rechtstaat Nieuw, 1(1), 45-57,

${ }^{34}$ Mulyani, Lilik., Op.Cit., h. 50.

${ }^{35}$ Rahardjo, Satjipto. (2010). Sosiologi Hukum: Perkembangan Metode dan Pilihan Masalah, Genta Publishing, Yogyakarta, h. 190. 
thinking habit, namely positivistic-legalistic thinking, departs from the rule of law. ${ }^{36}$ This is different from the sociology of law that departs from reality in the field, which sees what is reality. The complexity, which exists in society and how reality shapes intentions by looking at the law from the other end of the telescope.

An interesting example is Stewart Macaulay's sociological research on contracts. In this research, it was found that contract making not only gives rise to contractual relations but also non-contractual relations. Law enforcement as a logical process can only imagine that making a contract will lead to a contractual relationship, there can be no other relationship other than that. In the research, Macaulay showed that not all contracts that have been made will be carried out by the parties that made them themselves. Sociologically the results of the study are very interesting and emphasize once again that law enforcement in society is not solely determined by the rules contained in the law, but is largely determined by the interests of the perpetrators there. Macaulay's research can be returned to the words of Chief Justice Holmes, namely that the law is not logic but experience. ${ }^{37}$

Law enforcement can be discussed in two broad categories, namely:38 (1) solely viewed from regulations, namely as a logical continuation or logical process of the creation of law and (2) as human involvement in the process of working of the law. The availability of law is related to access to the law. Legal mobilization is also determined by how much the law is available to the public or how easily it can reach the people so that they can be used and this variable differs from one nation to another.

In the theory of the formation of a good legal product, there are ways or methods to make good legal products so that the implementation or enforcement is well accepted in the community. A good legal product is a legal product with as much material as possible taken from the common law but the container is given an authoritarian law form, and also a law can be long-lasting and obeyed by society if it has philosophical, sociological, and juridical characteristics. If there is a legal product that does not have one of the validity characteristics of the eating legal product, it can be said that the legal product is a poor legal product. Because if it does not contain the sociological nature of the legal product it is made without looking at the conditions that exist in the community so that in its manufacture it is only careless, fake, and fabricated. As a result, a legal product is ineffective or when enforced in the community and the binding capacity of the community is very low, and disobedience to the principles and limitations of regional capacity in the preparation of such legal products which in many cases hinder the achievement of regional autonomy objectives. In this case, community involvement will largely determine aspects of effective law enforcement. And the objectives of the government will be

${ }^{36}$ Galanter, Marc,"Keadilan di Berbagai Ruang: Lembaga Peradilan, Penataan Masyarakat serta Hukum Rakyat" dalam Ihromi, T.O. (2010). Antropologi Hukum: Sebuah Bunga Rampai, Yayasan Obor Indonesia, Jakarta, h. 95.

${ }^{37}$ Amarini, Indriati., Op. Cit., h. 86.

${ }^{38}$ Mubayyinah, Fira. (2016). Memotret Penegakan Hukum di Indonesia. Al Hikmah, 6(1), 1-8, doi: https://doi.org/10.36835/hjsk.v6i1.2795, h. 5-6. 
difficult to realize if people do not participate. This means that the law must be born from the legal construction of society which is legalized by the authorities. It must come from the concretization of the values that live in society. The progress of the Pound's view is on the emphasis on the meaning and function of legal formation. This is where the beginnings of the function of law as a famous social change tool.

Legal effectiveness is a process that aims to make the law effective. The situation can be reviewed based on several benchmarks of effectiveness. According to Soerjono Soekanto that there are five factors, namely: 1. The law itself. 2. Law enforcement. 3. Facilities and facilities. 4. Society. 5. Culture. ${ }^{39}$ The juridical consequence of the enactment of a legal product that does not have juridical and sociological nature is that the legal product cannot last long and the attachment to the community is very weak and then the effectiveness of the law is ineffective so that a legal product is effective in society, so a legal product shall determine as a good legal product so that the legal product is good and smooth and the effectiveness of the law is effective. Legal products that are sociological and juridical, for example, are the Criminal Law Act which is currently in force, which in this law has explained clearly and in detail about the provisions that are considered criminal in a form of norms Concrete laws are outlined in the form of article clauses. ${ }^{40}$ When the Criminal Code has fulfilled the juridical and sociological aspects in a fairly balanced manner, then this legal product has a very strong tie in the community, valid for a relatively long time, accepted by the community, and then the effectiveness of the effect is also strong in the community.

The sociological appearance of law enforcement becomes clearer when we are willing to come down to the characteristics of the parties involved in law enforcement. The sociological discourse and description of law enforcement were well encompassed and different from law enforcement that works with the use of regulatory and logical instruments. The sociology of law that observes the reality in the legal world sees that law enforcement is not a neutral activity, but rather has its social structure, so that it differs from time to time, from system to system and from one place to another.

\section{CONCLUSION}

Based on the description of the problems that have been discussed, then the conclusions can be drawn namely as follows:

By including the sociological stage as part of the activities of forming or drafting legal products, it can teach us a lesson that it turns out that the preparation of legal products is not just a juridical process. The processes of transformation from social desires into laws and regulations both in political and sociological contexts do not only occur at the time of the formation of a regulation.

${ }^{39}$ Soekanto, Soerjono. Op.Cit., h. 463.

${ }^{40}$ Ariyanti, Vivi. (2019). Kebijakan Penegakan Hukum dalam Sistem Peradilan Pidana Indonesia. Jurnal Yuridis, 6(2), 33-54, doi: http://dx.doi.org/10.35586/jyur.v6i2.789, h.44-45. 
Even at the operational stage, these processes continue and continually correct the legal products that have been produced. The development of law from the paradigm of power to reform towards the main goal of the law suggests that some enlightenment of the law must be implemented, namely: First, the law must not only be a tool to achieve rationality, but the law itself must be rational. Secondly, to ensure that rational law work can realize its objectives, efficient action must be supported by the law enforcement device. Third, the importance of putting a substance into a legal form is very closely related to the influence of the social structure of society, because the law should realize its goals. The sociology of law appearance of law enforcement becomes clearer especially views on the characteristics of the parties involved in law enforcement. The discourse and description of law enforcement were encompassed and it has differences with the use of regulatory and logical instruments. Sociology of law observes the reality of law enforcement as not a neutral activity and differs from one another time, system, or place.

\section{REFERENCES}

Agustiwi, Asri. (2016). Hukum sebagai Instrumen Politik dalam Era Globalisasi, Rechtstaat Nieuw, 1(1), 45-57.

Amarini, Indriati. (2017). Evaluasi Aktualisasi Pancasila melalui Harmonisasi Hukum, Kosmik Hukum, 17(2), 80-92, doi: 10.30595/kosmikhukum.v17.i2.2326.

Ariyanti, Vivi. (2019). Kebijakan Penegakan Hukum dalam Sistem Peradilan Pidana Indonesia. Jurnal Yuridis, 6(2), 33-54, doi: http://dx.doi.org/10.35586/jyur.v6i2.789.

Aryani, Nyoman Mas \& Hermanto, Bagus. (2018). Gagasan Pengaturan yang Ideal Penyelesaian Yudisial maupun Ekstrayudisial Pelanggaran Hak Asasi Manusia di Indonesia. Jurnal Legislasi Indonesia, 15(4), 369-383.

Buana, Mirza Satria \& Vikalista, Ellisa. (2019). Kontestasi Negara, Agama Mayoritas dan Hak Asasi Manusia (HAM) dalam Peraturan Daerah Bernuansa Syariah, Arena Hukum, 12(1), 43-63, doi: https://doi.org/10.21776/ub.arenahukum.2019.01201.3.

Choudhury, Nafay. (2017). Revisiting Critical Legal Pluralism: Normative Contestations in the Afghan Courtroom. Asian Journal of Law and Society, 4(1), 229-255, doi: 10.1017/als.2017.2.

Dwisvimiar, Inge. (2011). Keadilan dalam Perspektif Filsafat Ilmu Hukum. Jurnal Dinamika Hukum, 11(3), 522-531, doi: http://dx.doi.org/10.20884/1.jdh.2011.11.3.179.

Fadli, Muhammad. (2018). Pembentukan Undang-undang yang Mengikuti Perkembangan Masyarakat. Jurnal Legislasi Indonesia, 15(1), 51-61.

Galanter, Marc,"Keadilan di Berbagai Ruang: Lembaga Peradilan, Penataan Masyarakat serta Hukum Rakyat" dalam Ihromi, T.O. (2010). Antropologi Hukum: Sebuah Bunga Rampai, Yayasan Obor Indonesia, Jakarta. 
Hartanto, Wenda. (2015). Kesadaran Hukum sebagai Aspek Dasar Politik Hukum Legislasi: Suatu Tinjauan Filsafat. Jurnal Rechtsvinding, 4(3), 469-483.

Herlina, Ning. (2018). Cita Hukum Pancasila dapat Berkembang dalam Batang Tubuh Undangundang Dasar Republik Indonesia 1945, Lex Librum: Jurnal Ilmu Hukum, 4(2), 673-679, doi: http://doi.org/10.5281/zenodo.1286112.

Jati, Rahendro. (2012). Partisipasi Masyarakat dalam Proses Pembentukan Undang-undang yang Responsif. Jurnal Rechtsvinding, 1(3), 329-342.

Kartika, I Gusti Ayu Putri \& Wijayanti, Asri. (2010). Belajar Argumentasi Hukum, Cetakan Pertama, Humanika Cerdas Harmoni, Surabaya.

Kusumah, Mulyana W. (1981). Perkembangan dan Ruang Lingkup Sosiologi Hukum. Jurnal Hukum dan Pembangunan, 11(1), 63-72, doi: http://dx.doi.org/10.21143/jhp.vol11.no1.838.

Maggalatung, A Salman. (2014). Hubungan antara Fakta Norma, Moral, dan Doktrin Hukum dalam Pertimbangan Putusan Hakim, Jurnal Cita Hukum, 2(2), 185-192, doi: 10.15408/jch.v1i2.1462.

Mubayyinah, Fira. (2016). Memotret Penegakan Hukum di Indonesia. Al Hikmah, 6(1), 1-8, doi: https://doi.org/10.36835/hjsk.v6i1.2795.

Mulyani, Lilis. (2010). Pendekatan Sosial dalam Penelitian Hukum, Jurnal Masyarakat dan Budaya, 12(3), 35-56, doi: http://dx.doi.org/10.14203/jmb.v12i3.150.

Mustaghfirin, H. (2011). Sistem Hukum Barat, Sistem Hukum Adat, dan Sistem Hukum Islam menuju sebagai Sistem Hukum Nasional sebuah Ide yang Harmoni, Jurnal Dinamika Hukum, 11(1), 89-96, doi: http://dx.doi.org/10.20884/1.jdh.2011.11.Edsus.265.

Pujirahayu, Esmi Warassih (2011). Pranata Hukum: Sebuah Telaah Sosiologis, Badan Penerbit Universitas Diponegoro, Semarang.

Putri, Kania Dewi Andhika \& Arifin Ridwan. (2019). Tinjauan Teoritis Keadilan dan Kepastian dalam Hukum di Indonesia. Mimbar Yustitia, 2(2), 142-158.

Rahardjo, Satjipto. (2010). Sosiologi Hukum: Perkembangan Metode dan Pilihan Masalah, Genta Publishing, Yogyakarta.

Ramadhan, Choky. (2018). Konvergensi Civil Law dan Common Law di Indonesia dalam Penemuan dan Pembentukan Hukum, Mimbar Hukum, 30(2), 213-229, doi: https://doi.org/10.22146/jmh.31169.

Sahlan, Sartono. (2010). The Other Laws di Era Otonomi Daerah (Studi Antropologi Hukum), Pandecta: Jurnal Penelitian Ilmu Hukum, 5(2), 149-159, doi: https://doi.org/10.15294/pandecta.v5i2.2301.

Setyowati, Peni Jati. (2016). Fungsi Filsafat, Agama, Ideologi dan Hukum dalam Perkembangan Politik di Indonesia, Yuridika, 82-107, doi: 10.20473/ydk.v31i1.1957. 
Sidharta, Bernard Arief. (2009). Refleksi tentang Struktur Ilmu Hukum Sebuah Penelitian tentang Fundasi Kefilsafatan dan Sifat Keilmuan IImu Hukum sebagai Landasan Pengembangan IImu Hukum Nasional Indonesia, Cetakan Ketiga, Mandar Maju, Bandung.

Simatupang, Taufik H. (2019). Mendudukkan Konsep Executive Review dalam Sistem Hukum Ketatanegaraan Inonesia, Jurnal Penelitian Hukum De Jure, 19(2), 217-230, doi: http://dx.doi.org/10.30641/dejure.2019.v19.217-229.

Sirajuddin, M. (2015). Eksistensi Norma Agama dan Pancasila dalam Pembentukan Peraturan Perundang-undangan, Nuansa: Jurnal Studi Islam dan Kemasyarakatan, 8(1), 27-39, doi: http://dx.doi.org/10.29300/nuansa.v8i1.323.

Soekanto, Soerjono. (1981). Perspektif Sosiologi Hukum terhadap Pembinaan Hukum. Jurnal Hukum dan Pembangunan, 11(5), 461-466, doi: http://dx.doi.org/10.21143/jhp.vol11.no5.864.

Sonata, Depri Liber. (2014). Metode Penelitian Hukum Normatif dan Empiris: Karakteristik Khas dari Metode Meneliti Hukum. Fiat Justisia: Jurnal IImu Hukum, 8(1), 15-35, doi: 10.25041/fiatjustisia.v8no1.283.

Subiharta, Subiharta. (2015). Moralitas Hukum dalam Hukum Praksis sebagai Suatu Keutamaan. Jurnal Hukum dan Peradilan, 4(3), 385-398, doi: http://dx.doi.org/10.25216/JHP.4.3.2015.385-398.

Suhardin, Yohanes. (2009). Fenomena Mengabaikan Keadilan dalam Penegakan Hukum, Mimbar Hukum, 21(2), 341-354, doi: https://doi.org/10.22146/jmh.16261.

Sutiyoso, Bambang. (2010). Mencari Format Ideal Keadilan Putusan dalam Peradilan. Jurnal Hukum lus Quia lustum, 17(2), 217-232, doi: https://doi.org/10.20885/iustum.vol17.iss2.art3.

Wijayanti, Widya. (2013). Eksistensi Undang-undang sebagai Produk Hukum dalam Pemenuhan Keadilan bagi Rakyat (Analisis Putusan Mahkamah Konstitusi Nomor 50/PUU-X/2012). Jurnal Konstitusi, 10(1), 179-204, doi: https://doi.org/10.31078/jk\%25x.

Yani, Ahmad. (2018). Sistem Pemerintahan Indonesia: Pendekatan Teori dan Praktek Konstitusi Undang-undang Dasar 1945, Jurnal IImiah Kebijakan Hukum, 119-135, doi: http://dx.doi.org/10.30641/kebijakan.2018.v12.119-135.

Yusa, I Gede \& Hermanto, Bagus. (2017). Gagasan Rancangan Undang-undang Lembaga Kepresidenan: Cerminan Penegasan dan Penguatan Sistem Presidensiil Indonesia. Jurnal Legislasi Indonesia, 14(3), 313-324. 